\title{
Pemodelan Dimensi Fraktal Multiskala untuk Mengenali Bentuk Daun
}

\section{Multiscale Fractal Dimension Modelling for Leaf Shape Recognition}

\author{
AZIZ RAHMAD, YENI HERDIYENI, AGUS BUONO, STEPHANE DOUADY
}

\begin{abstract}
Abstrak
Penelitian ini membangun model untuk membedakan bentuk daun menggunakan dimensi fraktal multiskala. Identifikasi tumbuhan obat sangat penting mengingat keanekaragaman hayati di Indonesia dan peran pentingnya di Indonesia. Identifikasi tanaman dapat dilakukan menggunakan analisis bentuk dengan daun sebagai cirinya. Dimensi fraktal multiskala adalah salah satu metode analisis bentuk yang menganalisis bentuk melalui kompleksitasnya. Empat tipe bentuk daun dari spesies berbeda dimodelkan dalam penelitian ini. Analisis multiskala mampu memberikan informasi tambahan mengenai alur perubahan luas bidang dilasi, namun tidak mencirikan bentuk daun yang diuji dalam penelitian ini.
\end{abstract}

Kata Kunci: bentuk daun, dimensi fraktal multiskala, tanaman obat.

\begin{abstract}
This research proposes a model to differentiate leaf shape using Multiscale Fractal Dimension. Identification of medicinal plants is important considering wide range of biodiversity in Indonesia and significant role of medicinal plants in Indonesia. Plant identification can be performed with shape analysis using leaf shape as a feature. Multiscale Fractal Dimension is a shape analysis method that analyze shapes through its complexity. In this research four types of leaf shapes taken from differnet species of Indonesian medicine plants has their shapes modelled with Multiscale Fractal Dimension. While multiscale analysis could provide additional information regarding dilation area change rate, it couldn't provide distinct features of leaf shapes in this experiment.
\end{abstract}

Keywords: leaf shape, medicinal plant, multiscale fractal dimension

\section{Pendahuluan}

Indonesia memiliki keanekaragaman hayati yang luas. Tanaman obat sebagai salah satu keanekaragaman hayati memiliki peran signifikan dalam kehidupan masyarakat Indonesia terutama pada bidang kesehatan karena harganya yang murah dan tidak memiliki banyak efek samping (Gogtay et al. 2002). Sekitar 20\% dari tanaman obat telah dibudidayakan masyarakat, tetapi hampir $80 \%$ sisanya hanya dapat diperoleh dari pengambilan langsung di hutan, sehingga memerlukan proses identifikasi. Proses identifikasi secara tradisional adalah hal yang sulit dan memerlukan tenaga profesional. Perkembangan teknologi saat ini pada bidang pengenalan pola dan citra memungkinkan otomatisasi identifikasi tanaman ini menggunakan citra tanaman.

Salah satu bagian tanaman yang umum digunakan untuk identifikasi adalah daun karena mudah terlihat, memiliki bentuk yang sederhana, selalu tersedia, dan dapat diambil untuk penelitian lebih lanjut tanpa membahayakan tanaman. Daun sangat cocok pada identifikasi otomatis karena mudah diambil fotonya dan relatif mudah dianalisis (Ceruti et al. 2011). Salah

\footnotetext{
${ }^{1}$ Departemen Ilmu Komputer, Fakultas Matematika dan Ilmu Pengetahuan Alam, Institut Pertanian Bogor, Bogor ${ }^{2}$ Laboratoire: Matiere et System Complex, Batiment Condorcet 10 rue Alice Domon et Leonie Duquet, Université Paris Diderot CC 705675205 Paris Cedex

*Penulis Korespondensi: Tel/Faks: 0251-8625584; Surel: aziz.rahmad12p@apps.ipb.ac.id
} 
satu ciri yang mudah dikenali pada daun tanaman adalah bentuknya. Ada 20 variasi bentuk daun yang telah diklasifikasikan (Benson 1957). Bentuk-bentuk ini dapat direpresentasikan polanya dalam model dimensi fraktal.

Dimensi fraktal menyatakan ruang yang ditempati sebuah bentuk dan dapat menjadi indikasi kompleksitas suatu bentuk. Salah satu teknik pemodelan dimensi fraktal yang terbukti paling akurat dan konsisten adalah Dimensi Bouligand Minkowski (Backes dan Bruno 2008). Bentuk daun sendiri bukan merupakan bentuk fraktal, jadi pemodelan fraktal ini membutuhkan estimasi yang mendekati model fraktal sebenarnya (Florindo 2012). Estimasi dimensi fraktal dapat dilakukan dengan regresi linear, namun informasi ciri bentuk yang lebih rinci dapat diperoleh menggunakan turunan pertama dari kurva regresi linear. Metode ini disebut sebagai analisis multiskala (Bruno 2008).

Penelitian yang dilaksanakan adalah memodelkan bentuk-bentuk daun dalam dimensi fraktal Bouligand-Minkowski menggunakan analisis multiskala. Efektivitas model ini akan diuji dengan pengklasifikasian citra urat daun secara otomatis.

\section{Metode}

\section{Data Penelitian}

Data yang digunakan adalah data citra daun yang dimiliki oleh Laboratorium Computer Vision Departemen Ilmu Komputer IPB. Citra berukuran 700x700 piksel dan telah diberi label berdasarkan bentuk daun masing-masing citra. Pelabelan dilakukan berdasarkan pengelompokkan bentuk daun menurut Benson (1957). Penelitian ini menggunakan empat bentuk daun yang umum pada tanaman obat Indonesia, yaitu cordate, ellips, ovate, dan lanceolate. 50 citra dari masing-masing bentuk daun digunakan dalam penelitian ini.

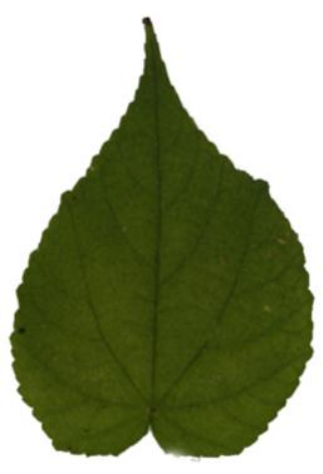

(a)

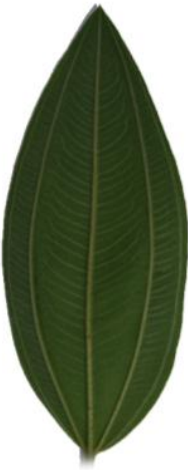

(b)

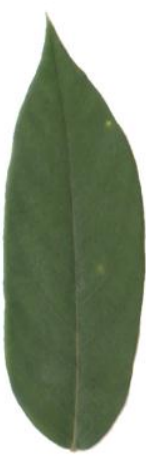

(c)

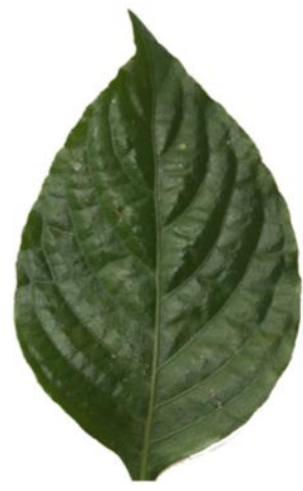

(d)

Gambar 1 Empat jenis bentuk daun yang dimodelkan pada penelitian ini, (a) cordate, (b) ellips, (c) lanceolate, dan (d) ovate.

\section{Praproses}

Setiap citra akan diseragamkan ukurannya untuk memastikan faktor ukuran tidak mempengaruhi hasil penelitian. Pada penelitian ini setiap citra diperkecil sehingga berukuran seperempat dari citra aslinya. Citra kemudian diubah menjadi hitam putih untuk menegaskan batas antara tepi daun dan latar belakang. Batas inilah yang menandakan bentuk dari daun tersebut.

\section{Pemodelan Fraktal}

Dimensi fraktal adalah ukuran fragmentasi pada suatu obyek (Backes dan Bruno 2008). Dimensi fraktal dapat mengidentifikasi kompleksitas suatu fraktal dengan membandingkan perubahan ketidakteraturan pada sebuah bentuk ketika skalanya diubah. Dimensi fraktal juga menggambarkan sifat self-similar suatu bentuk. Sebuah obyek dikatakan self-similar apabila 
obyek tersebut terdiri dari bagian-bagian yang mirip dengan obyek itu sendiri. Sifat self-similar adalah ciri penting pada fraktal, karena fraktal memiliki sifat self-similar di berbagai skala.

Dimensi fraktal yang digunakan pada penelitian ini adalah Bouligand-Minkowski yang dapat dirumuskan sebagai berikut.

$$
D B=2-\lim _{r \rightarrow 0} \frac{\log A(r)}{\log (r)}
$$

$A(r)$ adalah jumlah elemen yang dihitung dan $r$ adalah ukuran jendela penghitung (Tricot 1995). Teknik penghitungan dimensi dalam penelitian ini adalah dilasi. Metode ini menghitung daerah pengaruh suatu bentuk dengan menghitung luas daerah bentuk $(A(r))$ setelah bentuk tersebut didilasi (diperbesar) dengan radius tertentu $(r)$. Metode ini tidak efisien karena luas daerah akan terus dihitung ulang pada setiap pertambahan radius sehingga waktu penghitungan akan bertambah seiring dengan pertambahan jumlah radius. Metode yang lebih efisien dan umum digunakan adalah Euclidean Distance Transform (EDT). EDT memiliki prinsip yang sama dengan dilasi. EDT mengukur jarak Euclid dari setiap titik latar belakang ke bentuk obyek lalu menghitung jumlah piksel $(A(r))$ yang memiliki nilai jarak yang sama dengan atau lebih kecil dari radius tertentu $(r)$. Hasil dari penghitungan ini dapat disajikan dalam kurva log-log $r$ $A(r)$ yang disebut sebagai kurva dilasi. Pada penelitian ini radius yang dihitung adalah hingga $r=100$. Contoh daerah pengaruh daun yang dihitung menggunakan EDT ditampilkan pada Gambar 2. Ilustrasi ini menggunakan modulo untuk menampilkan garis batas daerah pengaruh bentuk daun yang ditampilkan pada Gambar 1 .

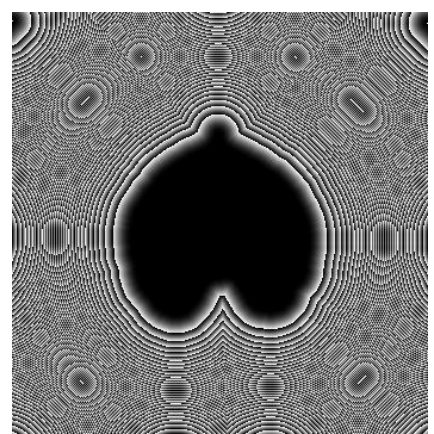

(a)

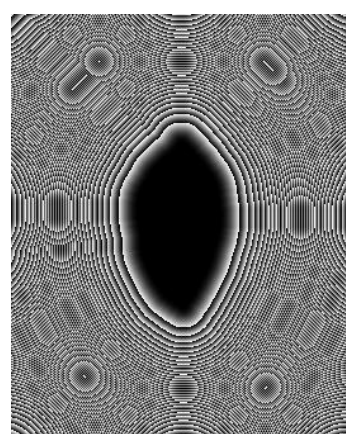

(b)

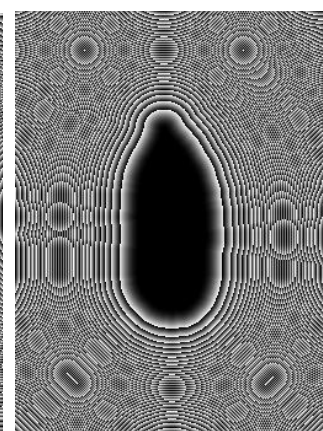

(c)

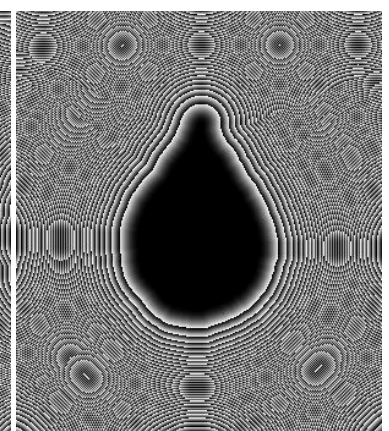

(d)

Gambar 2 Daun dan daerah pengaruhnya, (a) cordate, (b) ellips, (c) lanceolate, dan (d) ovate.

Kurva dilasi yang dihasilkan adalah kurva empiris dan perlu estimasi untuk memperoleh nilai dimensi fraktalnya. Penghitungan ini menggunakan analisis multiskala. Analisis multiskala akan menghitung turunan pertama dari kurva dilasi. Hasil dari analisis ini adalah sebuah kurva baru yang membandingkan perubahan dimensi fraktal terhadap perubahan radius dilasi. Kurva ini kemudian dapat disebut sebagai kurva Multiscale Fractal Dimension (MFD). Rumusnya adalah sebagai berikut.

$$
M F D=2-\frac{d u(t)}{d t}
$$

Pada rumus tersebut $u(t)$ merepresentasikan turunan dari $\log (A(r))$ dan $t$ merepresentasikan $\log (r)$. Apabila kurva dilasi melihat perubahan luas bidang berdasarkan ukuran, kurva MFD melihat tingkat perubahan luas tersebut. Kurva yang dihasilkan lebih kaya informasi. Kurva dilasi selalu linear karena luas bidang akan terus meningkat apabila radiusnya meningkat. Kurva MFD tidak selalu linear karena tingkat perubahan luas bidang tidak selalu meningkat. Hal ini memungkinkan kurva untuk memiliki nilai maksimum dan minimum lokal. Nilai-nilai ini dapat mewakili keseluruhan kurva dalam jumlah yang lebih kecil dan masih menyimpan informasi penting dari kurva (Bruno et al. 2008). 
Masalah utama dari kurva MFD adalah ukurannya yang besar. Banyak data yang diperoleh merupakan informasi yang redundan sehingga dapat memperlambat proses komputasi dan mengaburkan batas antara dimensi fraktal dari citra yang berbeda. Masalah ini dapat diselesaikan dengan menerapkan deskriptor pada kurva. Ada beberapa deskriptor yang dapat digunakan untuk kurva MFD, salah satunya yang dikenal memiliki waktu komputasi yang singkat adalah deskriptor Fourier. Deskriptor Fourier juga dapat menghasilkan data yang tidak dipengaruhi oleh rotasi, translasi, dan skala, sehingga sesuai untuk pengenalan pola khususnya citra (Florindo et al. 2011).

Masalah lain adalah kecenderungan turunan untuk memperbesar derau berfrekuensi tinggi. Hal ini dapat mempengaruhi hasil akhir karena seringkali bentuk yang dianalisis memiliki derau yang tak diperkirakan. Derau ini dapat dikurangi dengan menggunakan filter low-pass pada citra, salah satunya yang digunakan dalam penelitian ini adalah Gaussian. Jadi deskriptor Fourier yang diterapkan pada kurva MFD penelitian ini dirumuskan sebagai berikut.

$$
\frac{d u(t)}{d t}=F^{-1}\left\{F\{u(t)\}\left\{g_{\sigma}(t)\right\}(j 2 \pi f)\right\}
$$

dengan $f$ sebagai frekuensi, $j$ sebagai bilangan imajiner dan $g_{\sigma}(t)$ adalah filter Gaussian yang diterapkan pada $\log (r)$ dan didefinisikan sebagai berikut.

$$
g_{\sigma}(t)=\frac{1}{\sigma \sqrt{2 \pi}} \exp \left(\frac{-t^{2}}{2 \sigma^{2}}\right)
$$

$\sigma$ adalah standar deviasi yang dapat diubah. Pada penelitian ini standar deviasi yang digunakan adalah 10.

Kurva yang baik memiliki interval yang seragam. Pada radius dilasi yang kecil luasan bentuk sangat dipengaruhi bentuk obyek. Hal ini menyebabkan interval antara titik data di radius kecil tidak seragam. Ada dua langkah untuk mengatasi masalah ini. Langkah pertama adalah menghapus titik data yang memiliki interval terlalu jauh. Langkah kedua adalah dengan menggunakan interpolasi linear untuk mengisi data yang renggang dengan rataan data di sebelahnya.

Deskriptor Fourier juga dapat menyebabkan fenomena Gibbs, yaitu lompatan data yang dihasilkan pendekatan Fourier pada kurva yang tidak kontinyu seperti kurva dilasi (Schroeder 1991). Solusi dari permasalahan ini adalah dengan menerapkan duplikasi dan refleksi pada kurva untuk membuat kurva seolah kontinyu lalu memotong kurva hasil pendekatan Fourier sesuai batasan kurva aslinya.

\section{Hasil dan Pembahasan Penghitungan Fraktal}

Hasil penghitungan fraktal dengan metode EDT ditampilkan pada Gambar 3. Setiap kurva pada diagram tersebut, yang disebut sebagai kurva dilasi, mewakili setiap data citra daun yang dimodelkan. Tipe bentuk yang berbeda diberi warna yang berbeda untuk memudahkan memahami data. Setiap kurva dilasi memiliki ciri khas yang sama yaitu bersifat linear. Setiap kurva dimulai dari nilai nol dan secara linear meningkat seiring dengan peningkatan radius dilasi. Hal ini menunjukkan bahwa luas area dilasi juga meningkat secara linear seiring peningkatan radius.

Hal berbeda yang dapat dilihat dari tiap kurva adalah tingkat kemiringan masing-masing kurva. Tingkat kemiringan ini menunjukkan tingkat pertambahan luas daun berbanding dengan pertambahan radius dilasinya. Semakin curam kurva maka berarti semakin tinggi tingkat pertambahan luasnya. Gambar 3 memperlihatkan kurva dilasi masing-masing tipe sebagian 
besar telah memiliki kemiringan yang khas, dengan rata-rata tipe daun cordate memiliki kurva dengan kemiringan tercuram dan disusul berturut-turut oleh ovate, lanceolate, dan ellips.

Dimensi fraktal konvensional dapat dikalkulasi dengan menghitung kemiringan ini. Kemiringan dapat dihitung menggunakan regresi linear menghasilkan nilai tunggal yang menjadi nilai dimensi fraktal dari bentuk tersebut. Penghitungan regresi linear pada kurva dilasi memberikan hasil dengan urutan serupa pada cordate, ovate, lanceolate, dan ellips, yaitu berturut-turut $0.9953,0.9947$. 0.9940, dan 0.9936 .

\section{Estimasi Fraktal}

Kurva MFD yang dihasilkan menggunakan analisis multiskala ditampilkan pada Gambar 4. Grafik tersebut menunjukkan kurva yang memiliki alur yang lebih bervariasi dibandingkan linearitas kurva dilasi pada Gambar 3. Ini berarti informasi yang dapat dijadikan pembeda pada kurva MFD lebih banyak dibandingkan kurva dilasi yang hanya memiliki kemiringan kurva sebagai pembedanya. Kurva ini memiliki lembah dan bukit sehingga memiliki nilai maksimum dan minimum lokal dan global. Lembah dan bukit ini terbentuk karena meskipun luas daerah dilasi bertambah secara linear seiring pertambahan radius dilasi, tingkat pertambahan luas itu sendiri tidaklah selalu linear. Informasi fluktuasi tingkat pertambahan luas inilah yang dicerminkan pada kurva MFD ini.

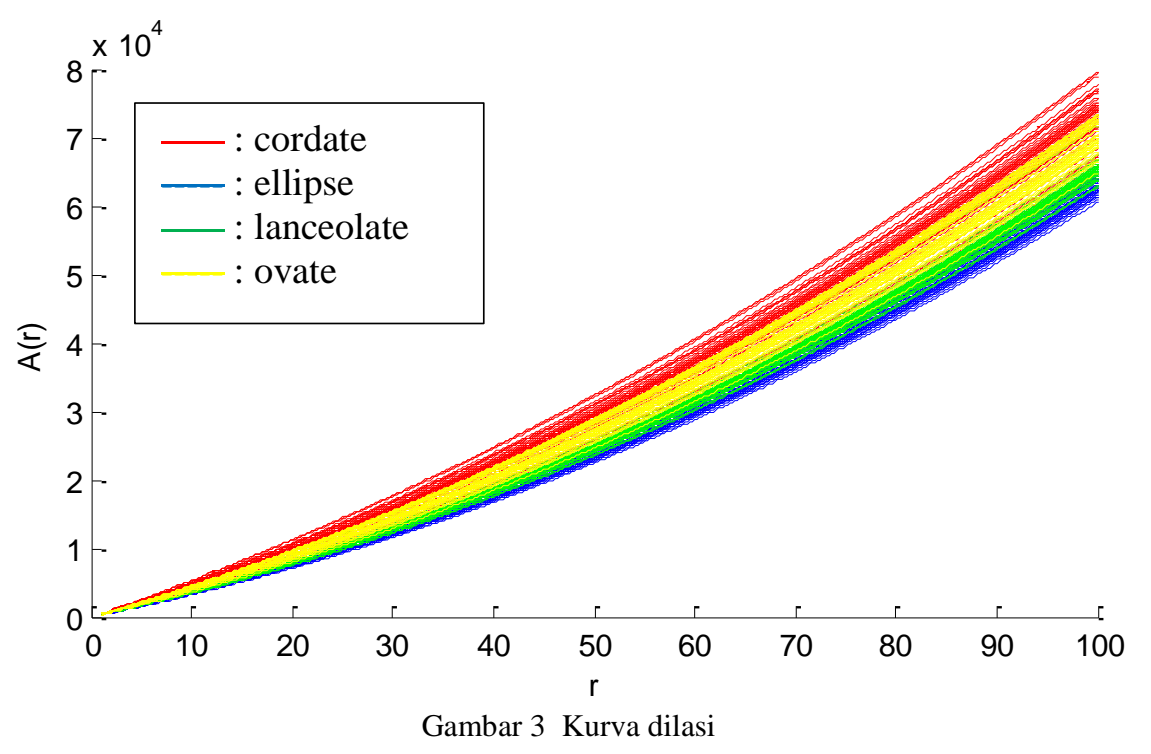

Secara umum seluruh kurva memiliki alur yang kurang lebih sama. Kurva menanjak secara curam dari awal dilasi hingga pada antara $r=10$ hingga $r=20$. Setelah tanjakan ini kurva naik turun dalam jarak kecil lalu kemudian menurun dengan landai hingga $r=100$. Meskipun memiliki alur yang jauh lebih bervariasi dibandingkan kurva dilasi, alur ini tampak serupa untuk setiap kurva. Urutan nilai dimensi fraktal multiskala tampak mengikuti urutan pada kurva dilasi, yaitu dengan cordate memiliki nilai dimensi tertinggi, diikuti ovate, lanceolate, dan dimensi terendah dimiliki oleh ovate. 


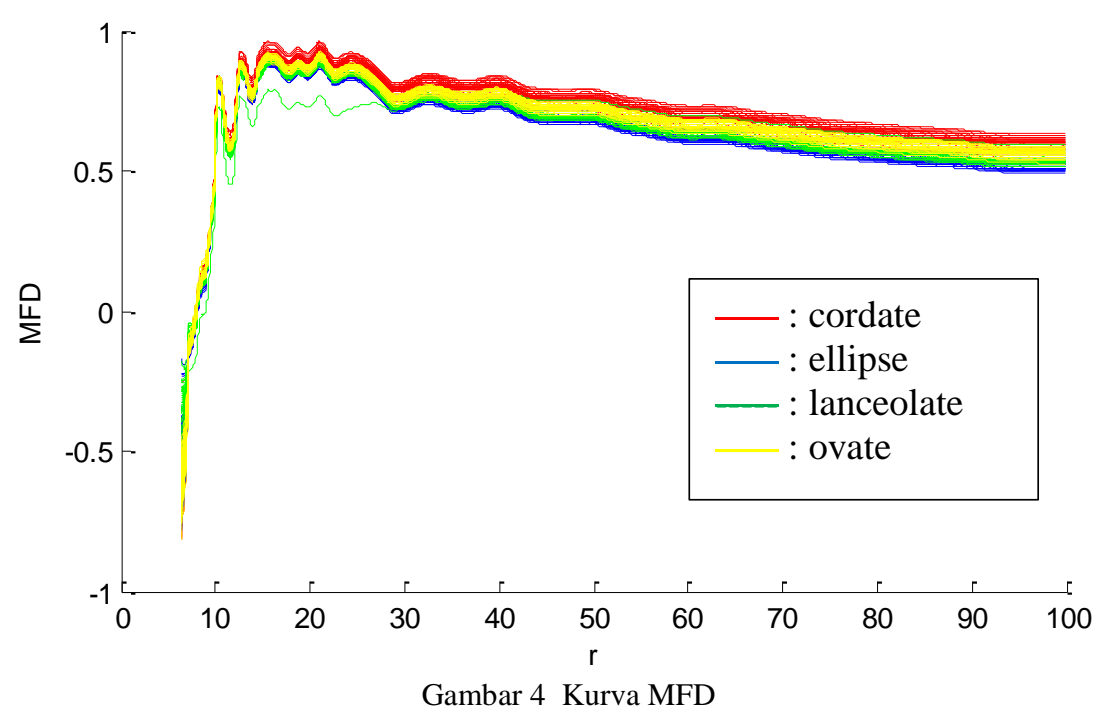

Kurva ini kemudian dikalkulasi menggunakan interpolasi agar pola dari tiap-tiap tipe bentuk daun dapat terlihat lebih jelas. Interpolasi pada kurva MFD ini dilakukan menggunakan metode fungsi radial basis (Radial Basis Function atau RBF), pada penelitian ini khususnya fungsi radial basis yang dipakai adalah fungsi linear. Hasil interpolasi dapat dilihat pada Gambar 5. Hasil ini menegaskan kembali kemiripan alur kurva MFD dan urutan nilai dimensi fraktalnya. Hal ini menunjukkan bahwa semua tipe bentuk daun yang digunakan pada penelitian ini memiliki alur fluktuasi yang serupa sehingga tidak mencirikan bentuk-bentuk daun yang berbeda.

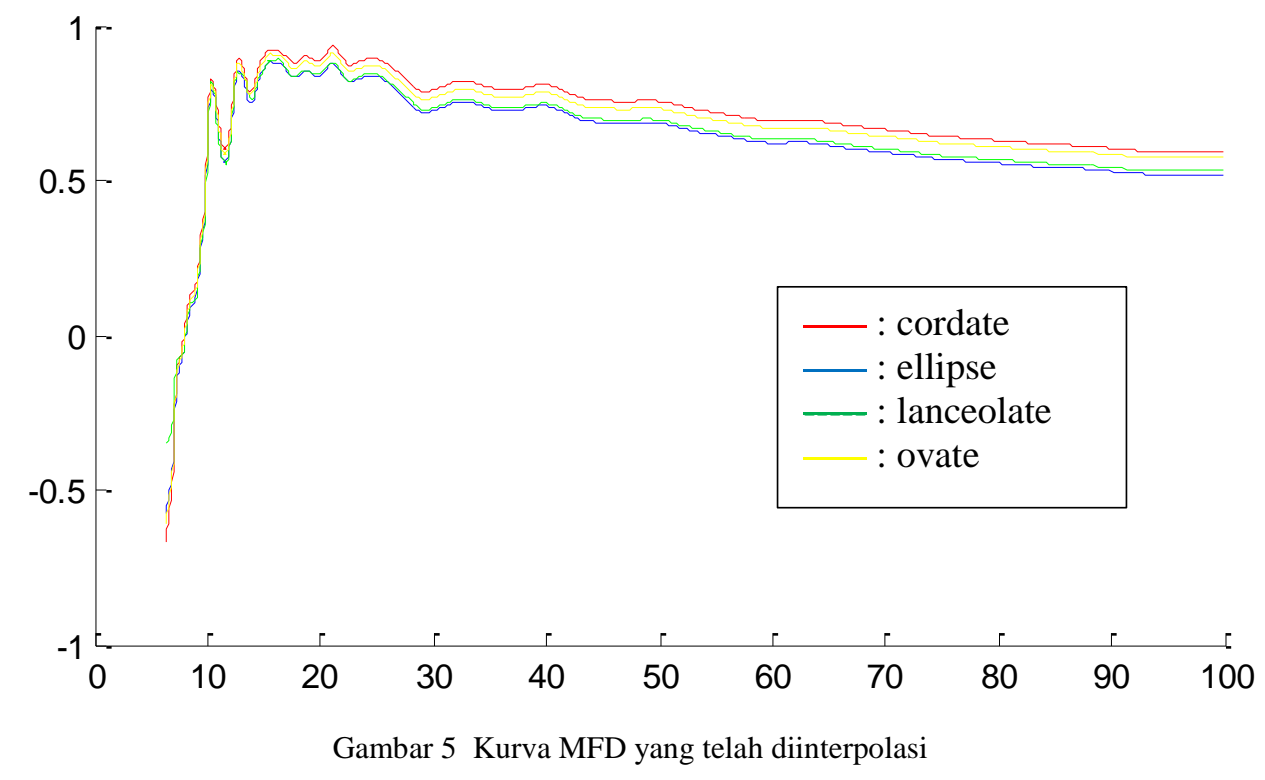

\section{Simpulan}

Penelitian ini mencoba memodelkan empat jenis bentuk daun menggunakan dimensi fraktal multiskala Bouligand-Minkowski. Penghitungan fraktal dilakukan menggunakan EDT dan estimasi fraktal dilakukan menggunakan analisis multiskala dengan deskriptor Fourier. Grafik yang dihasilkan menunjukkan bahwa kedua tahapan tersebut mampu menampilkan nilai dimensi fraktal yang khas pada tiap-tiap tipe daun dengan urutan sesuai nilai dimensi fraktalnya dari yang tertinggi adalah cordate, ovate, lanceolate, dan ellips. Analisis multiskala mampu memberikan informasi tambahan mengenai tingkat fluktuasi perubahan luas seiring dengan perubahan radius dilasi. Informasi ini sayangnya tidak mencirikan tiap-tiap bentuk secara unik 
karena seluruh bentuk daun yang diuji memiliki alur yang serupa. Hal ini menunjukkan bahwa penghitungan fraktal sudah cukup mencirikan bentuk daun yang digunakan pada penelitian ini.

\section{Daftar Pustaka}

Backes AR, Bruno OM. 2008. Fractal and Multi-Scale Fractal Dimension analysis: a comparative study of Bouligand-Minkowski method. INFOCOMP Journal of Computer Science, 7(2): 74-83.

Benson L. 1957. Plant Classification. Boston (US): D.C. Heath and Company.

Bruno OM, Backes AR. 2008. A New Approach to Estimate Fractal Dimension of Texture Image. Heidelberg: Springer.

Bruno OM, Costa LDF. 2004. A parallel implementation of exact Euclidean distance transform based on exact dilations. Microprocessors and Microsystems. 28(3): 107-113.

Bruno OM, de Oliveira Plotze R, Falvo M, de Castro M. 2008. Fractal dimension applied to plant identification. Information Sciences, 178(12): 2722-2733.

Cerutti G, Tougne L, Mille J, Vacavant A, Coquin D. 2011. Guiding Active Contours for Tree Leaf Segmentation and Identification. Dans Cross-language Evaluation Forum (September). Lyon (FR): Laboratoire d'Informatique en Image et Systèmes d'information.

Florindo JB, Backes AR, de Castro M, Bruno OM. 2012. A comparative study on multiscale fractal dimension descriptors. Pattern Recognition Letters, 33(6): 798-806.

Gogtay NJ, Bhatt HA, Dalvi SS, Kshirsagar NA. 2002. The use and safety of nonallopathic Indian medicine. Drug Saf. 25:1005-1019.

Mandelbrot BB. 1982. The Fractal Geometry of Nature. New York: W.H. Freeman and Company.

Zuhud, EAM. 2009. Potensi Hutan Tropika Indonesia sebagai Penyangga Bahan untuk Kesehatan Bangsa. Jurnal Bahan Alam Indonesia. 6(6). 